\title{
Diatom assemblages and their associated environmental factors in upland peat forest rivers
}

\author{
Connie O'Driscoll ${ }^{1}$, Elvira de Eyto ${ }^{2}$, Michael Rodgers ${ }^{1}$, Mark O’Connor ${ }^{1}$, Zaki-ul-Zaman Asam ${ }^{1}$, \\ and Liwen Xiao ${ }^{1 *}$ \\ ${ }^{1}$ Civil Engineering, National University of Ireland, Galway, Republic of Ireland \\ ${ }^{2}$ Marine Institute, Newport, Co. Mayo, Republic of Ireland \\ "Corresponding author: Liwen Xiao; Email: liwen.xiao@ nuigalway.ie; Tel: +353 91 494188;
}

Fax: +35391494507

\begin{abstract}
The acid-sensitive upland blanket peat catchments are important habitats for diatom assemblages. In this study, the distribution patterns of epilithic diatom assemblages in the streams of upland forested blanket peat in north-west of Ireland are presented and the associated environmental factors are discussed. A total of 43 sites in 16 rivers were sampled. Multivariate analysis highlighted alkalinity and conductivity as the main physicochemical drivers of riverine diatom assemblages. Contrary to expectations nutrients were not found to have a major influence on the diatoms. A major flood event had a significant impact on the diatom assemblage, and one year after the event, long stalked diatom taxa were still largely absent from the river, indicating that floods could be one of the important factors affecting diatom assemblages. However, the ecological status of the affected sites, as determined by the EQR, did not alter from before to after the flood. The results of this study could be applied to similar acid-sensitive upland peat forest catchments and used as the benchmark to assess the impact of forest operations and peat degradation on ecological status.
\end{abstract}

Keywords: Diatom assemblage; Blanket peat forest; Nutrients; Low alkalinity; Acid-sensitive; Flood; Water framework directive (WFD) 


\section{INTRODUCTIONS}

The Water Framework Directive (WFD) requires EU Member States to achieve 'good ecological status' for all water bodies by 2015 (European Union, 2000). Assessing, maintaining and restoring good ecological status of aquatic ecosystems has become a priority for river basin management and water protection in Europe (Eloranta and Soininen, 2002; Kelly and Wilson, 2004; Leira and Sabater, 2005; Kelly et al., 2008; Urrea and Sabater, 2009). Diatoms have been used successfully as indicators of the ecological quality of aquatic ecosystems worldwide (Kelly et al., 1998; Leira and Sabater, 2005; Hering et al., 2006; Chen et al., 2008). This is due to their 1) being well established in the food web, 2) responding rapidly to the majority of physical, chemical and biological changes in water bodies and 3) having a one-stage life cycle and very short generation time (Stevenson and Yan, 1999). Many diatom indices such as the Trophic Diatom Index (TDI) in the UK (Kelly and Whitton, 1995) and Germany (Coring et al., 1999); the Trophienindex (TI) in Austria (Rott et al., 1999) and the Indice Biologique Diatomique (IBD) in France have been developed for the assessment of trophic conditions. However, to meet the requirements of the WFD, trophic indices must be compared to reference conditions. Ecological quality ratios (EQR's) have recently been derived for diatom indices, specifically the TDI, to allow the observed TDI to be compared with an expected reference index value (Kelly et al., 2006). For the EQR to be considered reliable and to meet WFD requirements, representative reference conditions need to be defined for a complete range of ecoregions and habitats. However, acid-sensitive and low alkalinity sites are underrepresented in the EQR (Kelly-Quinn et al., 2004; Kelly et al., 2006). The importance of characterising diatom assemblage in low alkalinity sites has been highlighted (Camburn and Charles, 2000; Tolotti, 2001; Cantonati and Lange-Bertalot, 2011).

Upland peat catchments in northwestern Europe are characterised as acid-sensitive areas. These areas contain the headwaters of rivers, many of which contain Red List species (e.g. salmonids and freshwater pearl mussels) which make them important biodiversity refuges. The main pressures to the rivers in these acid-sensitive areas include forestry operations and peat degradation. Since the 1950s, large areas of upland blanket peat have been afforested in northwestern European countries. Risk assessments on receiving waters have shown that forest operations result in increased phosphorus (P) release (Nisbet, 2001; Cummins and Farrell, 2003; 
Nieminen, 2003; Rodgers et al., 2010). Acidification of surface waters draining forested catchments is also a concern (Jenkins et al., 1990; Ormerod et al., 1991; and Allott et al., 1997). Peat degradation and projected climate change lead to increased dissolved organic carbon (DOC) export, decreased $\mathrm{pH}$ in receiving waters and increased flood events (Fealy et al., 2010; Cantonati and Lange-Bertalot, 2011). In view of these multiple and increasing pressures, it is crucial to have a thorough understanding of the diatom assemblages which will be used in assessing ecological change in the rivers draining the acid-sensitive upland peat catchments. The main purpose of this study therefore is to characterise the diatom assemblages of these rivers and ascertain the environmental drivers of assemblage composition. To the best of our knowledge, there is no research focused on the diatom assemblages and their associated environmental factors in oligotrophic rivers draining upland forested blanket peat.

The rivers in upland blanket peat catchments are usually spate, prone to flash flooding and exhibit a quick response time to precipitation (Müller, 2000). The diatom assemblages are therefore likely to contain taxa well adapted to high flows and frequent changes in water level. It is unknown, however, how these assemblages respond to extreme flood events and the implications of flood events on the ecological status of sites. During the sampling period of this study, an extreme flood event occurred in one of our study rivers, where $52 \mathrm{~mm}$ of rain fell in two hours (Dalton et al., 2010). Such events are considered to occur once in 250 years (Fealy et al., 2010). This provided a fortuitous opportunity to assess the impact of an extreme flood on diatom assemblages.

\section{MATERIALS AND METHODS}

\subsection{Study sites and characterisation}

This study was based in three adjoining catchments, located in Mayo in the north west of Ireland (Figure 1). Most of the catchments are covered in blanket peat and overlie quartzite and schist bedrock. The catchment systems are described as acid oligotrophic and have a low buffering capacity (Byrne et al., 2004). The main land uses are forestry and sheep grazing and the catchments receive an average precipitation of over 2,000 mm per year (Dalton et al., 2010). Commercial coniferous plantations were planted in blocks or coupes starting in the 1950s 
(O'Driscoll et al., 2011). A total of 43 sites in 16 rivers were selected for this study, 36 located in forested areas and the other 7 sites in unforested peatland.

Diatoms were sampled in June 2009. Water samples were taken at each sampling site and anaylsed on the same day for alkalinity and colour using standard procedures (APHA, 1989). Phosphorus, nitrate-nitrogen and ammonia were measured using a Konelab 20 Analyser (Konelab Ltd., Finland). Water temperature, pH and conductivity were recorded in the field, and altitude, catchment area, stream order (Strahler, 1957), and Shreve stream order (Shreve, 1966) were extracted from GIS maps of the areas. All the sites were sampled in baseflow conditions and so diatoms and environmental variables are representative of conditions at base flow. A subset of samples was taken the following year to examine the impact of an extreme flood event on diatom assemblages in one of the study rivers. $52 \mathrm{~mm}$ of rain falling in two hours, an event considered to occur once in 250 years (Fealy et al., 2010). Twelve samples were taken in the Srahrevagh and Glennamong rivers in summer 2010, one year after the flood event. The Glennamong is in a neighbouring sub-catchment and was un-impacted by the flood event and so is treated as a control.

\subsection{Diatom sampling, preparation and identification}

Diatoms were collected and prepared in accordance with Kelly et al. (1998). Taxa were identified to species level where possible and counted at x 1,000 magnification using an Olympus BX-51 microscope equipped with a x 100 phase contrast objective (numerical aperture: 1.25). At least 300 valves were identified and counted per slide (Krammer and Lange-Bertalot, 1986, 1997, 2000, and 2004). Certain taxa were difficult to identify and the approaches adopted for these species were as follows. Achnanthidium minutissimum varieties were split into types based on Potapova and Hamilton (2007). Three types were found in these samples: the 'capitate' morph which corresponds to 'type a' in these samples; 'linear' corresponds to 'type b' and 'narrow-linear' corresponding to 'type c'. These three Achnanthidium groups were largely present in girdle view and so were enumerated separately in girdle view and then divided between the three morphological groups based in proportion to their relative abundance. Eunotia exigua, also present in high numbers in girdle view, was difficult to distinguish from Eunotia tenella and Eunotia meisteri and so the three were combined and considered as Eunotia exigua 
complex. Gomphonema parvulum has been described with a number of varieties and attributed environmental preferences, however populations in these samples had high morphological variability, and so have been termed Gomphonema parvulum complex.

\subsection{Data analysis and statistics}

Diatom species richness $(\boldsymbol{S})$ was determined from the number of species counted on each slide. The Shannon-Weiner index $\left(\boldsymbol{H}^{\prime}\right)$, which measures the proportional abundances of species in a community was calculated (Shannon and Weaver, 1963). In order to relate the diatom community to water quality, the revised Trophic Diatom Index (TDI), which quantifies the impact of nutrients on diatom assemblages, was calculated for each site (Kelly et al., 2008). The scores range from 0 (very low nutrients) to 100 (very high nutrients). The TDI was compared with reference assemblage characteristics and the EQR was calculated taking into account the relationship between nutrient gradients and diatom assemblages with season and alkalinity (Kelly et al., 2006). An EQR close to 1 indicates an un-impacted diatom assemblage, whereas a value close to 0 indicates a severe impact (Kelly et al., 2006).

\subsection{Relationship of diatom assemblages with environmental variables}

Diatom data were first analysed with detrended correspondence analysis (DCA) (Hill and Gauch, 1980) to determine the gradient length. The length of the gradient was greater than 2 standard deviation units (4.641), and so unimodal ordination techniques were chosen (ter Braak, 1987). Correspondence analysis (CA), was used to determine the major patterns of variation in species composition data following which canonical correspondence analysis (CCA), was used to relate diatom assemblages to all predictor environmental variables (ter Braak and Verdonschot, 1995). Data exploration highlighted significant correlation between $\mathrm{pH}$ and alkalinity and so $\mathrm{pH}$ was dropped from further analyses. To reduce further the environmental variables to those correlated significantly with the derived axes, step-wise forward selection and Monte Carlo permutation tests were used. Only those taxa that were observed in more than 5\% of the samples were included in analyses of taxa abundances to minimize the influence of rare taxa. Taxa abundance was square root transformed in all analyses to reduce the effect of highly variable population densities on ordination scores. Environmental variables were appropriately transformed before 
analysis to reduce skewed distributions and all ordinations were performed using CANOCO version 4.1 (ter Braak and Šmilauer, 1998).

\subsection{Impact of extreme flood event on diatom assemblages}

To assess the impact of the extreme flood on diatom assemblages, similar analysis as that for determining the relationship of diatom assemblages with environmental variables was adapted. The Srahrevagh and Glennamong in 2009 and 2010 were used as environmental variables corresponding to before and after the flood respectively. Taxa abundance was square root transformed to reduce the effect of highly variable population densities on ordination scores.

\section{RESULTS}

\subsection{Environmental characteristics of the sites}

Nutrient concentrations in the study sites were very low, with the maximum $\mathrm{PO}_{4}-\mathrm{P}, \mathrm{NH}_{4}-\mathrm{N}$ and $\mathrm{NO}_{3}-\mathrm{N}$ concentrations of $6.27 \mu \mathrm{g} \mathrm{L}^{-1}, 122.12 \mu \mathrm{g} \mathrm{L}^{-1}$ and $97.02 \mu \mathrm{g} \mathrm{L}^{-1}$, respectively (Table 1). Based on the nutrient concentrations all the study sites can be described as oligotrophic. Conductivities of the sites were between $67 \mu \mathrm{S} \mathrm{cm}^{-1}$ to $251 \mu \mathrm{S} \mathrm{cm}^{-1}$ (Table 1). $\mathrm{pH}$ values of the sites ranged from 3.55 to 8.49 (Table 1). Alkalinity in the study sites varied between $-2.7 \mathrm{mg} \mathrm{L}^{-1}$ $\mathrm{CaCO}_{3}$ and $68.8 \mathrm{mg} \mathrm{L}^{-1} \mathrm{CaCO}_{3}$ (Table 1).

\subsection{Diatom species composition}

Of the 57 taxa found, 52 taxa were observed in more than $5 \%$ of the samples. The five most abundant taxa were Achnanthes oblongella, Fragilaria capucina var. gracilis, Eunotia exigua, Tabellaria flocculosa, and Achnanthidium minutissimum Type A, present in $77 \%, 60 \%, 65 \%$, $60 \%$, and $67 \%$ of the sites, respectively. Species richness ranged from a minimum of 5 to a maximum of 25. The Shannon Weiner diversity index ranged from 0.40 to 2.79. TDI values ranged from 1.7 to 46.7 . There was no correlation between TDI and $\mathrm{P}\left(\mathrm{PO}_{4}-\mathrm{P} \mu \mathrm{g} \mathrm{L}{ }^{-1}\right)$ of which all values are less than $10 \mu \mathrm{g} \mathrm{L}^{-1}$ (Spearman rho $=-0.049, p=0.75$, d.f. $=41$ ). There was a significant correlation between alkalinity and TDI (Spearman rho $=0.396, p<0.05$, d.f. $=41$ ). EQR values ranged from 0.65 to 1.12 , with a median value of 1 . 
CA ordination results showed that $20.2 \%$ of diatom assemblage variance was explained on axis 1, with a further $12 \%$ explained on axis 2 (Figure 2). There are two clear groupings from this graph, the first in the top left hand side quadrat and the second in the bottom right hand side quadrat which cluster along a gradient. Taxa situated on the left side of diagram included Achnanthes oblongella, Fragilaria capucina var. gracilis and Gomphonema parvulum complex. Taxa situated on the right side included the Eunotia exigua complex, Pinnularia appendiculata, Eunotia paludosa and Tabellaria flocculosa. Taxa with higher values on axis 2 included Eunotia paludosa and Eunotia microcephala. Taxa with maximum abundances and lowest values on axis 2 included the Eunotia exigua complex and Tabellaria flocculosa.

\subsection{Important environmental variables}

The first two axes explained a significant proportion of variance in the diatom taxa data $(\mathrm{P}<$ 0.01). CCA with forward selection identified all variables except colour to be significant $(\mathrm{P}<$ 0.05) accounting for significant portions $(60 \%)$ of the total variance in diatom species composition (Table 2). Alkalinity explained the largest portion (30\%) of the total unconstrained variance. CCA ordination plots identified three groupings of sites (Figure 3a, b). The first one comprised sites with high conductivity and alkalinity and featured Reimeria sinuata, Gomphonema truncatum, Diatoma tenue, Cocconeis placentula and Ctenophora pulchella. The second group comprised sites with high conductivity, low alkalinity, and first order streams with small upstream catchment area. These sites were dominated by Eunotia paludosa, Pinnularia appendiculata and Eunotia microcephala. The third group comprised sites with low conductivity, low alkalinity and higher stream order and upstream catchment area. Brachysira neoexilis, Tabellaria flocculosa, Eunotia exigua complex and Eunotia implicata were the common taxa observed at these sites.

\subsection{Impact of extreme flood on diatom assemblages}

Table 3 shows the representative diatom taxa in the Glennamong and Srahrevagh rivers a week before and one year after the extreme flood event. The flood altered the diatom assemblages in the Srahrevagh. The Glennamong, which was not affected by the flood, had five out of seven of the most common diatom species occurring in 2009 and 2010. Only one common species 
Fragilaria capucina var. gracilis found in 2009 was replaced by Eunotia incisa and Pinnularia appendiculata in 2010. However, in Srahrevagh, 4 of the 6 common species found in 2009 were replaced in 2010 (Table 3). CCA ordination results showed that the environmental variables explain $29 \%$ of the species data (Figure 4). Axis 1 separates the Glennamong and Srahrevagh rivers and explains $65.4 \%$ of the variation. Axis 2 corresponds to the year 2009 and 2010 and a significantly larger variation can be seen in the impacted Srahrevagh river when compared to the Glennamong. This was owing to several species which were present in 2009 such as Gomphonema truncatum, Gomphonema acuminatum, Epithemia adnata, Hannaea arcus and Ctenophora pulchella and disappear entirely from the samples taken 12 months later in 2010. All sites in the impacted and non impacted rivers had an EQR between 0.8 and 1.0.

\section{DISCUSSION}

\subsection{Low alkalinity gradient}

Multivariate analysis indicated that variables driving the distribution of diatom assemblages in the study catchments were associated with physiography i.e., alkalinity, ionic concentration, stream order, upstream catchment area and Shreve stream order rather than nutrients. The geology of the western side of the study catchments is mostly comprised of quartzite and schist with the Glennamong, Altahoney and Maumaratta rivers being well represented by taxa with a preference for low $\mathrm{pH}$ such as the Eunotia genus. Representative diatoms include Red List species such as Eunotia implicata, Eunotia bilunaris var. mucophila, Eunotia paludosa and Eunotia rhomboidea (Lange-Bertalot, 1996). Cantonati and Lange-Bertalot (2011) highlight the importance of the Eunotia group and suggest in the threatened naturally-acidic and low-alkalinity waters, Eunotia species might be play a fundamental role as indicators of ecological status. Even when the dominant geology is granite/ schist, the presence of small veins of buffering geology (dolomite and wacke) (Fealy et al., 2010) can considerably raise the alkalinity of receiving waters and hence cause a shift to more circumneutral assemblages. For example, Gomphonema olivaceoides, abundant in the Srahrevagh is known to have an ecological preference for upland low nutrient streams with calcareous geology. In stream longitudinal alkalinity gradients are represented by a shift from upper sites abundant in Achnanthes oblongella to sites further down the catchment with a more diverse spread of species such as Gomphonema truncatum, Reimeria 
sinuata and Cocconeis placentula. Therefore in peatland catchments the underlying geology is crucial in determining diatom assemblages.

Low alkalinity in rivers is closely correlated with episodic acid pulses and the presence of many $\mathrm{pH}$ tolerant diatom species indicates that acidification may be a main driver of assemblage composition. Anthropogenic acidification has been known to occur due to afforestation (Battarbee et al., 2010) and peat degradation and associated DOC leaching and increased $\mathrm{pH}$ (Monteith and Evans, 2005; Jennings et al., 2010). It is also possible that these assemblages represent naturally acidic conditions. However, while many diatom metrics exist to measure acidity (Van Dam and Mertens, 1994; Kwandrans, 2007; Andren and Jarlman, 2008) none consider the expected value of sites as required by the WFD. Nevertheless, characterisations of diatom assemblages in these acid sensitive waters will prove crucial in the future in determining acidification impacts.

\subsection{Low nutrient concentrations}

The rivers included in this study can all be defined as oligotrophic, as the annual phosphorus concentrations were less than $20 \mu \mathrm{g} \mathrm{PO}_{4}-\mathrm{P} \mathrm{L}^{-1} .44$ of the 57 diatom taxa found in the study sites are known to be nutrient sensitive (sensitivity values of 1 and 2, Kelly et al., 2005). Although the range of TDI values measured in this study includes some moderately high values (e.g. 40, 42.2, 46.7), the EQR which corrects for alkalinity was found to be close to 1 for all the sites, indicating a 'good' or 'high' ecological status. While the felling of forest sub-catchments in the study areas has been shown to increase the phosphorus and sediment loads in receiving waters (Rodgers et al., 2010), it appears that the ecological quality of the diatom assemblages has not been impacted. We can therefore support the characterisation of riverine diatoms in this area as oligotrophic and lacking any sign of anthropogenic nutrient enrichment from forestry activities. These sites therefore represent reference conditions with respect to nutrient status. However, this result should be treated with a certain amount of caution as work is still ongoing on the use of EQR's in Ireland, particularly in low alkalinity sites (i.e. $<6.8 \mathrm{mg} \mathrm{L}^{-1} \mathrm{CaCO}_{3}$ (B. Kennedy, EPA Ireland, pers. comm.).

\subsection{Spate nature of rivers}


It is highly likely that the lack of impact due to nutrient enrichment on the diatom assemblages is due to the quick flushing of nutrients through these spate rivers. The diatom assemblages of first order streams that are liable to flash flooding and receive high annual precipitation (> 2000 $\mathrm{mm}$ ) have high abundances of Achnanthes oblongella. Achnanthes oblongella attaches to the substrate by its valve face and mucilage which is likely to give it protection and resilience to floodwaters. Achnanthes oblongella showed resilience even to the major flood experienced in the Srahrevagh, having a maximum abundance both before and after the flood in 2009 at the upper first order sites. However the long stalked species such as Gomphonema truncatum, loosely attached taxa such as Epithemia adnata and Fragilaria capucina var. gracilis which were abundant at the lower sites before the flood disappeared from samples taken in 2010. They were replaced by r-strategists with small cell size, low biomass and fast growth such as the Achnanthidium types (Biggs et al., 1998), the Gomphonema parvulum complex and Reimeria sinuata, indicating that episodic flood events can be an important structuring factor for diatom assemblages. In their study, Cambra and Gomà (1997) noticed a shift from well structured diatom communities with a high diversity index to less well structured, low diversity communities dominated by r-strategist species after a perturbation. Despite the substantial shift in assemblages, no change in ecological status in terms of nutrients was evident the year after the flood. This highlights the sturdiness of the EQR in determining the ecological status of upland rivers draining forested blanket peat. However these results are based on a subset of samples taken the year after flood. Due to the highly dynamic nature of these rivers single sampling provides a snapshot overview of ecological status. Kelly et al. (2006) recommends six replicates of samples should be taken over two to three years to eliminate annual, seasonal and spatial variation. Further study should examine the influence of spatial and temporal variation on the diatom assemblages of acid-sensitive upland blanket peat catchments.

\section{CONCLUSIONS}

This study has provided a characterisation of diatom assemblages in upland peatland rivers characteristic of the west of Ireland and related alkalinity and conductivity as the main physicochemical drivers of the diatom assemblages. This highlights the importance of the underlying geology in determining diatom assemblage composition. Multivariate analysis indicated that nutrient enrichment from forestry activities did not stand out as having a major 
influence on the diatom assemblages. Therefore these upland peatland rivers represent reference conditions with respect to nutrient status. Further work needs to be carried out to determine if the acidic nature of the sites is a response to anthropogenic impacts or natural acidity. Spatial gradients highlighted an upstream-downstream trend and future work should concentrate on how the spatial and temporal variation impacts the diatom assemblages in these spate rivers. The results of this study could be applied to similar upland peat forest catchments and used as the benchmark to assess the impact of ongoing forest harvesting on ecological status. The impact of the flood on diatom assemblage structure is evident at the lower sites; however, this had no bearing on the EQR status. Future work needs to be carried out to determine how long (if at all) it takes for these species to return.

\section{ACKNOWLEDGEMENTS}

The authors gratefully acknowledge the funding from the Department of Agricultural, Fisheries and Food in Ireland, COFORD, Ireland EPA, Coillte and the Marine Institute. They also acknowledge the assistance of Mr. Bryan Kennedy, Mary O'Brian, Mary Dillane and Liz Ryder. The comments made by two anonymous reviewers are very much appreciated.

\section{REFERENCES}

Allott, N., Brennan, M., Cooke, D., Reynolds, J., and Simon, N. 1997. Stream chemistry, hydrology and biota, Galway-Mayo region. In: A study of the effects of stream hydrology and water chemistry in forested catchments on fish and macroinvertebrates, AQUAFOR Report 4, COFORD, Dublin, Ireland.

Andrén, C. and Jarlman, A., 2008. Benthic diatoms as indicators of acidity in streams. Fundam. Appl. Limnol. 173: 237-253.

APHA, 1989. Standard Methods for the Examination of Water and Wastewater. American Public Health Association, Washington, DC, p. 1220. 
Battarbee, R.W., Charles, D.F., Bigler, C., Cumming, B.F., and Renberg, I., 2010. Diatoms as indicators of surface-water acidity. In: Smol, J.P. and E.F. Stoermer (Eds), The Diatoms. Applications for the Environmental and Earth Sciences. 2nd rev. ed. pp. 98-121.

Biggs, B.J.F., Stevenson, R.J. and Lowe, R.L., 1998. A habitat matrix conceptual model for stream periphyton. Archiv für Hydrobiologie. 143, 21-56.

Byrne, C. J., Poole, R., Dillane, M., Rogan, G., Whlean, K.F., 2004. Temporal and environmental influences on the variation in sea trout (Salmo trutta L.) smolt migration in the Burrishoole system in the west of Ireland from 1971 to 2000. Fish. Res. 66 (1), 85-94.

Cambra, J. and Gomà, J., 1997. Flood effects on algal biodiversity in a Mediterranean river. Lagascalia. 19 (1-2), 463-478.

Camburn, K.E. and Charles, D.F., 2000. Diatoms of low-alkalinity lakes in the northeastern United States. The Academy of Natural Sciences of Philadelphia, Scientific Publications, Philadelphia, USA. Special Publication 18: 1-152.

Cantonati, M., and Lange-Bertalot, H., 2011. Diatom monitors of close-to-pristine, very low alkalinity habitats: three new Eunotia species from springs in Nature Parks of the south-eastern Alps. J Limnol., 70 (2): 209-221.

Chen, G., Dalton, C., Leira, M., Taylor, D., 2008. Diatom-based total phosphorus (TP) and pH transfer functions for the Irish Ecoregion. J Paleolimnol. 40 (1), 143-163.

Coring, E., Schneider, S., Hamm, A., Hofmann, G., 1999. Durchgehendes Trophiesystem auf der Grundlage der Trophieindikaation mit Kieselalgen. Deutscher Verband für Wasserwirtschaft und Kulturbau e.V, Koblenz. 
Cummins, T., and Farrell, E. P., 2003. Biogeochemical impacts of clearfelling and reforestation on blanket peatland streams I. Phosphorus. Forest Ecol. Manag. 180 (1-3), 545-555.

Dalton, C., Jennings, E., Taylor, D., O'Dwyer, B., Murnaghan, S., Bosch, K. et al., 2010. Past, current and future interactions between pressures, chemical status and biological quality elements for lakes in contrasting catchments in Ireland. EPA/ERTDI PROJECT \# 2005-W-MS40 Draft Report 290 pp.

Eloranta P. and Soininen J., 2002. Ecological status of some Finnish rivers evaluated using benthic diatom communities. Journal of Applied Phycology 14: 1-7.

European Union 2000. Directive 2000/60/EC of the European Parliament and of the Council of 23 October 2000 establishing a framework for community action in the field of water policy. Official Journal of the European Communities, L327, 1-73.

Fealy, R., Allott, N., Broderick, C., de Eyto, E., Dillane, M., Erdil, R.M. et al., 2010. Review and Simulate Climate and Catchment Responses at Burrishoole. Marine Institute \# SS/CC/07/002(01) 152pp.

Hering D., Johnson R.K., Krama S., Schmutz S., Szoszkiewicz K. and Verdonschot P.F.M., 2006. Assessment of European streams with diatoms, macrophytes, macroinvertebrates and fish: a comparative metric-based analysis of organism response to stress. Freshwater Biol. 51, 17571785.

Hill, M.O., Gauch, H.E.J., 1980. Detrended correspondence analysis: an improved ordination technique. Vegetatio. 42 (1), 47-58.

Jenkins, A., Cosby, B.J., Ferrier, R., Walker, T.A.B., and Miller, J.D. (1990) Modelling stream acidification in afforested catchments. An assessment of the relative effects of acid deposition and afforestation. Journal of Hydrology, 120: 163-181. 
Jennings, E., Allott, N., Arvola, L., Jarvinen, M., Moore, K., Naden, P., Nic Aongusa, C., Noges, T. and Weyhermeyer, G. (2010) 'Impacts of climate on the flux of dissolved organic carbon from catchments'. In D.G. George (ed.) The Impact of Climate Change on European Lakes. Springer (Aquatic Ecology Series, 4), 199-200, 507pp.

Kelly, M.G., Whitton, B.A., 1995. The Trophic Diatom Index: a new index for monitoring eutrophication in rivers. J. Appl. Phycol. 7, 433-444.

Kelly, M.G., Cazaubon A., Coring E. et al., 1998. Recommendations for the routine sampling of diatoms for water quality assessments in Europe. J Appl. Phycol. 10, 215-224.

Kelly, M.G. and Wilson S., 2004. Effects of phosphorus stripping on water chemistry and diatom ecology in an eastern lowland river. Water Res. 38, 1559-1567.

Kelly, M.G., Yallop, M.L., Hirst, H. and Bennion, H., 2005. Sample collection. Version 2.1. 11pp. Unpublished DARES/DALES protocol. http://craticula.ncl.ac.uk/dares/methods.htm

Kelly, M.G., Juggins, S., Bennion, H., Burgess, A., Yallop, M., Hirst, H., King, L., Jamieson, J., Guthrie, R. and Rippey, B., 2006. Use of Diatoms for Evaluating Ecological Status in UK Freshwaters. Draft final report to Environment Agency. Bristol. 170 pp.

Kelly, M., Juggins, S., Guthrie, R., Pritchard, S., Jamieson, J., Rippey, B., Hirst, H. and Yallop, M., 2008. Assessment of ecological status in U.K. rivers using diatoms. Freshwater Biology. 53, 403-422.

Kelly-Quinn, M., Baars, J-R., Bradley, C., Dodkins I., Harrington, T.J., Ni Chathain, B., O'Connor, M., Rippey, B., Trigg, D. 2004. Characterisation of reference conditions and testing of typology of rivers (RIVTYPE). Draft report to the EPA.

Krammer, K. and Lange-Bertalot, H., 1986. Die Süsswasserflora von Mitteleuropa 2:

Bacillariophyceae. Teil 1: Naviculaceae. Gustav Fisher Verlag, Stuttgart. 
Krammer, K. and Lange-Bertalot, H., 1997. Die Süsswasserflora von Mitteleuropa, II:2.

Bacillariophyceae. Teil 2: Bacillariaceae, Epithemiaceae, Surirellaceae. 2te Auflage. Gustav Fisher Verlag, Stuttgart.

Krammer, K. and Lange-Bertalot, H., 2000. Süsswasserflora von Mitteleuropa 2:

Bacillariophyceae. Teil 3: Centrales, Fragilariaceae, Eunotiaceae. 2te Auflage. Gustav Fischer Verlag, Stuttgart.

Krammer, K. and Lange-Bertalot, H., 2004. Süsswasserflora von Mitteleuropa 2:

Bacillariophyceae. Teil 4: Achnanthaceae. Kritische Ergänzungen zu Achnanthes s.l., Navicula s. str., Gomphonema. Spektrum Akademischer Verlag/ Gustav Fisher, Heidelberg.

Kwandrans, J. 2007. Diversity and ecology of Benthic Diatom Communities in relation to acidity, acidification and recovery of lakes and rivers. Andrzej Witkowski Edited Diatom Monographs. 9: 1-169.

Lange-Bertalot, H. 1996. Rote Liste der limnischen Kieselalgen (Bacillariophyceae) Deutschlands. Schriften-Reihe für Vegetationskunde. 28: 633-677.

Leira, M. and S. Sabater, 2005. Diatom assemblages distribution in Catalan rivers, NE Spain, in relation to chemical and physiographical factors. Water Res. 39 (1), 73-82.

Monteith, D.T. and C.D. Evans. 2005. The United Kingdom Acid Waters Monitoring Network: a review of the first 15 years and introduction to the special issue. Environmental Pollution. 137: 3-13.

Müller, M., 2000. Hydrogeographical studies in the Burrishoole Catchment, Newport, Co. Mayo, Ireland: affects of afforestation on the run-off regime of small mountain spate river catchments. Verhandlung Internationale Vereinigung Limnologie 27, 1146-1148. 
Nieminen, M., 2003. Effects of clear-cutting and site preparation on water quality from a drained Scots pine mire in southern Finland. Boreal Environment Research. 8, 53-59.

Nisbet T.R., 2001. The role of forest management in controlling diffuse pollution in UK forestry. Forest Ecol. Manage. 143, 215-226.

O’Driscoll, C., Rodgers, M., O’Connor, M., Asam, Z., de Eyto, E., Poole, R. and Xiao, L., 2011. A potential solution to mitigate phosphorus release following clearfelling in peatland catchments. Water, Air and Soil Pollution 221: 1-11.

Ormerod, S.J., Rutt, G., Weatherley, N.S., and Wade, K. 1991. Detecting and managing the influence of forestry on river systems in Wales: Results from surveys, experiments and models. In: Irish Rivers: Biology and Management (M.W. Steer, ed.) Royal Irish Academy, Dublin. pp 163-184.

Potapova, M. and P. B. Hamilton, 2007. Morphological and ecological variation within the Achnanthidium minutissimum (Bacillariophyceae) species complex1. J Phycol. 43 (3): 561-575.

Rodgers, M., O’Connor, M., Healy, M.G., O’Driscoll, C., Asam, Z., Nieminen, M., Poole, R., Müller, M., Xiao, L. 2010. Phosphorus release from forest harvesting on an upland blanket peat catchment. Forest Ecol. Manag. 260 (12), 2241-2248.

Rott, E., Pipp, E., Pfister, P., van Dam, H., Ortler, K., Binder, N. and Pall, K., 1999. Indikationslisten für Aufwuchsalgen in Österreichischen Fliessgewassern. Teil 2: Trophieindikation. Bundesministerium fuer Land- und Forstwirtschaft, Wien. 248 pp.

Shannon, C.E. and Weaver, W., 1963. The Mathematical theory of Communication. Urbana, $125 \mathrm{pp}$.

Shreve, R. L., 1966. Statistical law of stream numbers. Journ. Geol. 74, 17-37. 
Stevenson, R. J., Pan, Y., 1999. Assessing environmental conditions in rivers and streams with diatoms. The Diatoms: Applications for the Environmental and Earth Sciences. Cambridge, University Press: 11-40.

Strahler, A. N., 1957. Quantitative analysis of watershed geomorphology. Trans. Amer. Geophys. Un., 38, 913-20.

ter Braak, C.J.F., 1987. Ordination. In: Data Analysis in Community and Landscape Ecology Jongman, (Eds. R.H.G., ter Braak, C.J.F., van Tongeren, O.F.R.), pp. 91-173, Pudoc, Wageningen,

ter Braak, C.J.F., Verdonschot, P.F.M., 1995. Canonical correspondence analysis and related multivariate methods in aquatic ecology. Aquat Sci. 57, 255-289.

ter Braak, C.J.F., Šmilauer, P., 1998. CANOCO Reference Manual and User's Guide to Canoco for Windows: Software for Canonical Community Ordination (version 4). Microcomputer Power. Ithaca, New York, p. 352.

Tolotti, M. 2001. Phytoplankton and littoral epilithic diatoms in high mountain lakes of the Adamello-Brenta Regional Park (Trentino, Italy) and their relationship to trophic status and acidification risk. J. Limnol. 60: 171-188.

Urrea G. and Sabater S., 2009. Epilithic diatom assemblages and their relationship to environmental characteristics in an agricultural watershed (Guadiana River, SW Spain). Ecol. Indicat. 9, 693-703.

van Dam, H., Mertens, A., Sinkeldam, J., 1994. A coded checklist and ecological indicator value of freshwater diatoms from the Nederlands. Netherlands Journal of Aquatic Ecology. 28, 117133. 
Table 1

Physical and chemical characteristics of the sites.

\begin{tabular}{|c|c|c|c|c|c|c|c|c|c|c|c|c|}
\hline & $\begin{array}{l}\text { Conductivity } \\
\left(\mu \mathrm{S} \mathrm{cm}^{-1}\right)\end{array}$ & $\begin{array}{c}\text { Alkalinity } \\
\left(\mathrm{mg} \mathrm{l}^{-1} \mathrm{CaCO}_{3}\right)\end{array}$ & $\begin{array}{l}\mathrm{PO}_{4}-\mathrm{P} \\
\left(\mu \mathrm{g} \mathrm{L}^{-1}\right)\end{array}$ & $\begin{array}{l}\mathrm{NH}_{4}-\mathrm{N} \\
\left(\mu \mathrm{g} \mathrm{L}^{-1}\right)\end{array}$ & $\begin{array}{l}\mathrm{NO}_{3}-\mathrm{N} \\
\left(\mu \mathrm{g} \mathrm{L}^{-1}\right)\end{array}$ & $\mathrm{pH}$ & $\begin{array}{l}\text { Colour } \\
(\mathrm{PtCo})\end{array}$ & $\begin{array}{c}\text { Temperature } \\
\left({ }^{\circ} \mathrm{C}\right)\end{array}$ & $\begin{array}{l}\text { Altitude } \\
(\mathrm{m})\end{array}$ & $\begin{array}{c}\text { Stream } \\
\text { Order }\end{array}$ & $\begin{array}{l}\text { Upstream } \\
\text { Catchment } \\
\text { Area (ha) }\end{array}$ & $\begin{array}{l}\text { Shreve } \\
\text { Index }\end{array}$ \\
\hline $\max$ & 251 & 68.8 & 6.3 & 122.1 & 97.0 & 8.49 & 283 & 20.4 & 341 & 4 & 1549 & 33 \\
\hline $\min$ & 67 & -2.7 & 3.1 & 6.5 & 0 & 3.55 & 38 & 11.8 & 20 & 1 & 10 & 1 \\
\hline mean & 120 & 12.1 & 4.1 & 50.6 & 20.3 & 4.43 & 121 & 16.1 & 128 & 2 & 474 & 8 \\
\hline median & 98 & 8.1 & 3.7 & 42.8 & 7.9 & 6.22 & 86 & 16.2 & 91 & 2 & 238 & 4 \\
\hline std dev & 50.6 & 17.09 & 0.9 & 32.5 & 27.8 & 4.08 & 78.8 & 2.5 & 94.4 & 1 & 516.9 & 10 \\
\hline
\end{tabular}




\section{Table 2}

Weighted correlation matrix showing the relationship between species axes and environmental variables (Figure 3 a and b). The environmental variables listed exerted significant $(\mathrm{P}<0.05)$ and independent influences on algal distributions.

\begin{tabular}{lcccc}
\hline Variables & Axis 1 & Axis 2 & Axis 3 & Axis 4 \\
\hline Conductivity $(\mu \mathrm{S} \mathrm{cm}-1)$ & -0.24 & 0.83 & -0.04 & -0.14 \\
Alkalinity $(\mathrm{mg} \mathrm{I-1} \mathrm{CaCO3)}$ & -0.89 & 0.28 & 0.00 & 0.00 \\
$\mathrm{PO}_{-3}{ }_{-3}^{\mathrm{P}}$ & 0.10 & 0.10 & 0.22 & 0.31 \\
$\mathrm{NH}+4-\mathrm{N}$ & 0.42 & 0.07 & -0.05 & -0.14 \\
$\mathrm{NO}-3-\mathrm{N}$ & 0.13 & -0.20 & -0.41 & 0.14 \\
Temperature $\left({ }^{\circ} \mathrm{C}\right)$ & -0.49 & 0.13 & -0.34 & 0.09 \\
Altitude $(\mathrm{m})$ & 0.21 & 0.01 & -0.32 & 0.57 \\
Stream Order & -0.35 & -0.30 & 0.13 & -0.39 \\
Upstream Catchment Area (ha) & -0.08 & -0.52 & 0.08 & -0.50 \\
Shreve Order & -0.21 & -0.45 & -0.02 & -0.46 \\
Percentage variance of species-environment relationship & 34.20 & 19.80 & 11.60 & 8.10 \\
Eigenvalues & 0.60 & 0.34 & 0.20 & 0.14 \\
\hline
\end{tabular}


Table 3. The main diatom taxa in the Glennamong and Srahrevagh rivers a week before and one year after the extreme flood event

\begin{tabular}{|c|c|c|c|}
\hline Glennamong & & Srahrevagh & \\
\hline & $\%$ of the total abundance & & $\%$ of the total abundance \\
\hline Main diatom species & & Main diatom species & \\
\hline 2009 Achnanthes oblongella & 18.8 & Achnanthes oblongella & 23.7 \\
\hline Fragilaria capucina var. gracilis & 18.7 & Fragilaria capucina var. gracilis & 11.4 \\
\hline Tabellaria flocculosa & 17.2 & Fragilaria capucina var. rumpens & 9.2 \\
\hline Achnanthidium minutissimum type A & 13.2 & Diatoma tenue & 5.7 \\
\hline Gomphonema parvulum & 11 & Epithemia adnata & 5.5 \\
\hline Eunotia rhomboidea & 5.4 & Synedra ulna & 5.5 \\
\hline 2010 Eunotia rhomboidea & 21.9 & Achnanthes oblongella & 19.8 \\
\hline Tabellaria flocculosa & 16.7 & Achnanthidium minutissimum Type A & 16.5 \\
\hline Achnanthes oblongella & 10.7 & Fragilaria capucina var. gracilis & 9.6 \\
\hline Eunotia incisa & 7.1 & Gomphonema parvulum & 8.1 \\
\hline Pinnularia appendiculata & 6.7 & Reimeria sinuata & 6.9 \\
\hline Gomphonema parvulum Complex & 6.7 & Cocconeis placentula & 6.6 \\
\hline Achnanthidium minutissimum Type A & 6.3 & Planothidium lanceolatum & 5.4 \\
\hline
\end{tabular}


1 Appendix A

2 Taxa Codes 


\begin{tabular}{|c|c|}
\hline Taxa & Label \\
\hline Achnanthes oblongella Østrup & $\mathrm{ACHOB}$ \\
\hline Achnanthidium minutissimum type $1 *$ sensu Potapova et Hamilton & ACHMNA \\
\hline Achnanthidium minutissimum type $2 *$ sensu Potapova et Hamilton & ACHMNB \\
\hline Achnanthidium minutissimum type $3 *$ sensu Potapova et Hamilton & ACHMNC \\
\hline Asterionella formosa Hassall & ASTRION \\
\hline Brachysira neoexilis Lange-Bertalot & BNEOEXILIS \\
\hline Cocconeis placentula Ehrenberg & COCCPLA \\
\hline Ctenophora pulchella (Ralfs ex Kützing) Williams \& Round & CTENOPUL \\
\hline Cyclotella radiosa Kützing ex. de Brébisson & CYCRADI \\
\hline Cymbella affinis Kützing & CAFFIN \\
\hline Diatoma mesodon (Ehrenberg) Kützing & DIAMESO \\
\hline Diatoma tenue Agardh & DIATEN \\
\hline Diploneis elliptica (Kützing) Cleve & DIPELLIP \\
\hline Encyonema gracile Ehrenberg & ENCYGR \\
\hline Encyonema silesiacum (Bleisch in Rabenhorst) Mann in Round, Crawford \& Mann & ENCYSIL \\
\hline Epithemia adnata (Kützing) Rabenhorst & EPITADNA \\
\hline Eunotia bilunaris var. mисорhila Lange-Bertalot and Norpel & EBILMUCO \\
\hline Eunotia exigua complex & EEXIGUA \\
\hline \multicolumn{2}{|l|}{ Eunotia exigua (de Brébisson ex Kützing) Rabenhorst } \\
\hline \multicolumn{2}{|l|}{ Eunotia tenella (Grunow in Van Heurck) Cleve } \\
\hline \multicolumn{2}{|l|}{ Eunotia meisteri (Hustedt) } \\
\hline Eunotia implicata Norpel, Lange-Bertalot \& Alles & EIMPLICT \\
\hline Eunotia incisa Smith ex Gregory & EINCISA \\
\hline Eunotia microcephala Krasske ex Hustedt & EMICRO \\
\hline Eunotia minor (Kützing) Grunow in Van Heurck & EMINOR \\
\hline Eunotia paludosa Grunow & EPALUD \\
\hline Eunotia rhomboidea Hustedt & ERHOMBO \\
\hline Eunotia subarcuatoides Alles, Norpel, Lange-Bertalot & ESUBARC \\
\hline Fragilaria capucina var. gracilis (Østrup) Hustedt & FRAGGRAC \\
\hline Fragilaria capucina var. rumpens (Kützing) Lange-Bertalot & FRAGRUM \\
\hline Frustulia rhomboides (Ehrenberg) De Toni & FRUSRHOM \\
\hline Gomphonema acuminatum Ehrenberg & GACUMIN \\
\hline Gomphonema clavatum Ehrenberg & GCLAVAT \\
\hline Gomphonema gracile Ehrenberg & GGRACIL \\
\hline Gomphonema minutum (Agardh) Agardh & GMINUT \\
\hline Gomphonema olivaceoides Hustedt & GOLIVAC \\
\hline Gomphonema parvulum complex (Kützing) Kützing & GPARVUL \\
\hline Gomphonema pumilum (Grunow) Reichardt \& Lange-Bertalot & GPUMIL \\
\hline Gomphonema sp. & GSPP \\
\hline Gomphonema truncatum Ehrenberg & GTRUNCAT \\
\hline Hannaea arcus (Ehrenberg) Patrick. in Patrick and Reimer & HANNARC \\
\hline Meridion circulare (Greville) Agardh & MERIOCIR \\
\hline Navicula lanceolata (Agardh) Kützing & NLANCEO \\
\hline Nitzschia dissipata (Kützing) Grunow & NITDISSI \\
\hline Nitzschia frustulum (Kützing) Grunow in Cleve \& Grunow & NITFRUST \\
\hline Nitzschia sp. & NITSPP \\
\hline Pinnularia appendiculata (Agardh) Cleve & PAPPEND \\
\hline Pinnularia rupestris Hantzsch in Rabenhorst & PRUPES \\
\hline Pinnularia subcapitata Gregory & PSUBCAP \\
\hline Planothidium lanceolatum (Brébisson ex Kützing) Lange-Bertalot & PLANOLAN \\
\hline Reimeria sinuata (Gregory) Kociolek \& Stoermer & REIMSIN \\
\hline Sellaphora pupula (Kützing) Mereschkowsky & SELLAPH \\
\hline Surirella sp. & SURIRELL \\
\hline Synedra ulna (Nitzsch) Ehrenberg & SYNEDUL \\
\hline
\end{tabular}


Appendix B

$7 \quad$ Sample codes

\begin{tabular}{|c|c|}
\hline Site & Label \\
\hline Srahrevagh 1 (Upper) & SR1 \\
\hline Srahrevagh 2 (Upper) & SR2 \\
\hline Srahrevagh 3 (Upper) & SR3 \\
\hline Srahrevagh 4 (Mid-Upper) & SR4 \\
\hline Srahrevagh 5 (Mid-Upper) & SR5 \\
\hline Srahrevagh 6 (Mid-Upper) & SR6 \\
\hline Srahrevagh 7 (Middle) & SR7 \\
\hline Srahrevagh 8 (Middle) & SR8 \\
\hline Srahrevagh 9 (Middle) & SR9 \\
\hline Srahrevagh 10 (Lower) & SR10 \\
\hline Srahrevagh 11 (Lower) & SR11 \\
\hline Srahrevagh 12 (Lower) & SR12 \\
\hline Glennamong 1 (Upper) & GL1 \\
\hline Glennamong 2 (Upper) & GL2 \\
\hline Glennamong 3 (Upper) & GL3 \\
\hline Glennamong 4 (Mid-Upper) & GL4 \\
\hline Glennamong 5 (Mid-Upper) & GL5 \\
\hline Glennamong 6 (Mid-Upper) & GL6 \\
\hline Glennamong 7 (Middle) & GL7 \\
\hline Glennamong 8 (Middle) & GL8 \\
\hline Glennamong 9 (Middle) & GL9 \\
\hline Glennamong 10 (Lower) & GL10 \\
\hline Glennamong 11 (Lower) & GL11 \\
\hline Glennamong 12 (Lower) & GL12 \\
\hline Glendahurk & $\mathrm{GH}$ \\
\hline Teevaloughan1 & TV1 \\
\hline Teevaloughan2 & TV2 \\
\hline Glennamong Control Stream & GCS \\
\hline Glennamong Study Stream & GSS \\
\hline Srahrevagh Study Stream & SSS \\
\hline Srahrevagh Control Stream & SCS \\
\hline Maumaratta Top & MT \\
\hline Maumaratta Bottom & MB \\
\hline Goulaun Top & GT \\
\hline Goulaun Bottom & GB \\
\hline Altahoney Top & AT \\
\hline Altahoney Bottom & $\mathrm{AB}$ \\
\hline Cottage Top & $\mathrm{CT}$ \\
\hline Cottage Bottom & $\mathrm{CB}$ \\
\hline Lodge Top & $\mathrm{LT}$ \\
\hline Lodge Bottom & LB \\
\hline Glendahurk & GHE \\
\hline Glenthomas & GTE \\
\hline
\end{tabular}




\section{Appendix C}

Physical characteristics of the individual sites

\begin{tabular}{|c|c|c|c|c|c|c|}
\hline & $\begin{array}{l}\text { Sample } \\
\text { Number }\end{array}$ & Temp $\left({ }^{\circ} \mathrm{C}\right)$ & Altitude (m) & $\begin{array}{c}\text { Stream } \\
\text { Order }\end{array}$ & $\begin{array}{l}\text { Upstream } \\
\text { Catchment } \\
\text { Area (ha) }\end{array}$ & $\begin{array}{c}\text { Shreve } \\
\text { Index }\end{array}$ \\
\hline Srahrevagh Upper & 3 & $18.0(0.2)^{\mathrm{a}}$ & $341.33(18.0)$ & 1 & 13 & 1 \\
\hline Srahrevagh mid-Upper & 3 & $19.1(0.1)$ & $181.33(1.2)$ & 2 & 168 & 3 \\
\hline Srahrevagh Middle & 3 & $20.4(0.6)$ & 130.0 & 2 & 266 & 4 \\
\hline Srahrevagh Lower & 3 & $20.0(0.2)$ & 40.0 & 3 & 690 & 8 \\
\hline Glennamong Upper & 3 & $14.2(0.1)$ & 230.0 & 2 & 191 & 2 \\
\hline Glennamong mid-Upper & 3 & $16.3(0.1)$ & $107.3(2.3)$ & 2 & 605 & 14 \\
\hline Glennamong Middle & 3 & $16.9(0.1)$ & 50.0 & 4 & 1145 & 29 \\
\hline Glennamong Lower & 3 & $17.5(0.1)$ & 20.0 & 4 & 1549 & 33 \\
\hline Glendahurk & 3 & 15.0 & 101.0 & 1 & 10 & 1 \\
\hline Teevaloughan 1 & 3 & 14.0 & 280.0 & 1 & 20 & 1 \\
\hline Teevaloughan2 & 3 & $14.1(0.10)$ & 268.0 & 1 & 32 & 1 \\
\hline Glennamong Study & 3 & 14.5 & 86.7 & 1 & 10 & 1 \\
\hline Glennamong Control & 3 & $14.4(0.1)$ & 55.8 & 1 & 10 & 1 \\
\hline Srahrevagh Study & 3 & 16.1 & 220.0 & 1 & 17 & 1 \\
\hline Srahrevagh Control & 3 & 16.7 & 240.0 & 1 & 23 & 1 \\
\hline Maumaratta & 3 & $14.0(1.8)$ & $95.0(63.6)$ & 2 & $473(255)$ & $3(2)$ \\
\hline Goulaun & 3 & $18.1(0.9)$ & $85.00(35.4)$ & 3 & $754(304)$ & $6(2)$ \\
\hline Altahoney & 3 & $12.8(2.3)$ & $80.00(28.3)$ & 3 & $1144(181)$ & $20(3)$ \\
\hline Cottage & 3 & $11.8(0.1)$ & $60.00(28.3)$ & 3 & 210 & $6(1)$ \\
\hline Lodge & 3 & $12.6(0.1)$ & $33.50(5.0)$ & 3 & 468 & $7(1)$ \\
\hline Glenthomas & 3 & 18.37 & 50.0 & 3 & 1429 & 17 \\
\hline Glendahurk (main) & 3 & 19.10 & 50.0 & 3 & 1211 & 25 \\
\hline
\end{tabular}

${ }^{\mathrm{a}}:$ () indicates standard deviation 


\section{Appendix D}

Chemical characteristics of the individual sites

\begin{tabular}{|c|c|c|c|c|c|c|c|c|}
\hline & $\begin{array}{l}\text { Sample } \\
\text { Number }\end{array}$ & $\begin{array}{l}\text { Conductivity } \\
\left(\mu \mathrm{S} \mathrm{cm}^{-1}\right)\end{array}$ & $\begin{array}{c}\text { Alkalinity } \\
\left(\mathrm{mg} \mathrm{L}^{-1}\right. \\
\left.\mathrm{CaCO}_{3}\right) \\
\end{array}$ & $\begin{array}{c}\mathrm{PO}_{4}-\mathrm{P} \\
\left(\mu \mathrm{g} \mathrm{L}^{-1}\right)\end{array}$ & $\begin{array}{l}\mathrm{NH}_{4}-\mathrm{N} \\
\left(\mu \mathrm{g} \mathrm{L}^{-1}\right)\end{array}$ & $\begin{array}{l}\mathrm{NO}_{3}-\mathrm{N} \\
\left(\mu \mathrm{g} \mathrm{L}^{-1}\right)\end{array}$ & $\mathrm{pH}$ & $\begin{array}{l}\text { Colour } \\
\text { (PtCo) }\end{array}$ \\
\hline Srahrevagh Upper & 3 & $93(3.5)^{\mathrm{a}}$ & $13.5(0.8)$ & $3.2(0.2)$ & $27.5(7.8)$ & $12.2(0.7)$ & $7.4(0.04)$ & $38(3.5)$ \\
\hline Srahrevagh mid-Upper & 3 & 141 & $37.0(0.6)$ & $4.7(0.2)$ & $26.1(5.1)$ & $7.1(0.5)$ & 7.7 & $49(1.7)$ \\
\hline Srahrevagh Middle & 3 & $152(12.0)$ & $37.9(5.2)$ & $3.72(0.4)$ & $19.2(5.9)$ & $8.8(2.4)$ & $7.3(0.15)$ & $41(3.4)$ \\
\hline Srahrevagh Lower & 3 & $213(0.7)$ & $68.8(0.3)$ & $5.4(0.6)$ & $6.5(2.1)$ & $0.6(0.1)$ & $8.5(0.01)$ & $56(0.6)$ \\
\hline Glennamong Upper & 3 & $67(0.3)$ & 0.1 & $4.8(0.6)$ & $36.6(1.9)$ & $97.0(33.2)$ & $5.6(0.07)$ & $104(5.8)$ \\
\hline Glennamong mid-Upper & 3 & $79(0.6)$ & $6.7(0.4)$ & $5.4(0.5)$ & $26.2(3.4)$ & $88.9(37.6)$ & $7.0(0.05)$ & $82(3.7)$ \\
\hline Glennamong Middle & 3 & $93(1.0)$ & $10.7(0.2)$ & $4.5(0.8)$ & $29.1(3.8)$ & $28.4(9.7)$ & $7.3(0.02)$ & $81(2.7)$ \\
\hline Glennamong Lower & 3 & 94 & $9.4(0.2)$ & $3.7(0.3)$ & $21.4(7.5)$ & $10.9(1.0)$ & $7.2(0.02)$ & $68(1.2)$ \\
\hline Glendahurk & 3 & $89(2.2)$ & $2.8(1.1)$ & $3.6(0.2)$ & $54.4(11.3)$ & $49.5(11.2)$ & $5.6(0.1)$ & $74(0.6)$ \\
\hline Teevaloughan 1 & 3 & $144(0.6)$ & $1.5(0.1)$ & $3.3(0.1)$ & $117.0(3.5)$ & $6.7(1.7)$ & $3.8(0.01)$ & $262(0.3)$ \\
\hline Teevaloughan2 & 3 & $122(0.3)$ & $1.7(0.1)$ & $3.5(0.2)$ & $77.7(2.4)$ & $34.1(2.3)$ & $4.8(0.01)$ & $141(1)$ \\
\hline Glennamong Study & 3 & $173(0.3)$ & $-1.7(1.3)$ & $4.0(0.3)$ & $73.9(4.5)$ & $39.0(2.1)$ & $3.9(0.01)$ & $256(0.3)$ \\
\hline Glennamong Control & 3 & $251(0.3)$ & $-2.7(0.3)$ & $3.8(0.3)$ & $39.3(3.8)$ & $3.43(0.8)$ & $3.5(0.01)$ & $264(0.3)$ \\
\hline Srahrevagh Study & 3 & $201(0.9)$ & $-2.4(0.3)$ & $6.3(0.2)$ & $110.7(4.0)$ & $2.0(1.1)$ & $3.6(0.01)$ & $283(0.3)$ \\
\hline Srahrevagh Control & 3 & $115(0.9)$ & 9.9 & $4.6(0.2)$ & $122.1(1.2)$ & $49.9(1.1)$ & $5.8(0.01)$ & $168(0.6)$ \\
\hline Maumaratta & 3 & $68(3.5)$ & $-0.5(0.5)$ & $4.9(1.6)$ & $43.4(0.1)$ & $0.0(4.4)$ & $5.8(0.01)$ & $138(5.0)$ \\
\hline Goulaun & 3 & $102(16.0)$ & $17.0(7.0)$ & $3.7(0.2)$ & $59.4(6.6)$ & $0.0(0.7)$ & $7.1(0.2)$ & $66(7.5)$ \\
\hline Altahoney & 3 & $75(1.5)$ & $-2.0(1.0)$ & $4.5(0.6)$ & $42.3(5.0)$ & $0.0(0.53)$ & 5.6 & $166(3.0)$ \\
\hline Cottage & 3 & $98(4.0)$ & 18.0 & $3.3(0.2)$ & $43.4(18.2)$ & $9.8(0.8)$ & $7.3(0.2)$ & $72(8.5)$ \\
\hline Lodge & 3 & $97(1.0)$ & 21.0 & $3.08(0.1)$ & $58.9(2.3)$ & $2.5(3.7)$ & 7.8 & $90(2.0)$ \\
\hline Glenthomas & 3 & $82(0.7)$ & $6.0(0.3)$ & $3.2(0.2)$ & $21.5(1.1)$ & $5.1(0.5)$ & $6.2(0.01)$ & $110(0.6)$ \\
\hline Glendahurk (main) & 3 & $87(0.3)$ & $11.4(0.3)$ & $3.5(0.2)$ & $65.1(1.1)$ & $2.1(0.5)$ & $6.3(0.01)$ & $64(0.6)$ \\
\hline
\end{tabular}


Figure 1. The position of 43 sites where riverine diatom assemblages were sampled in 2009 in the North West of Ireland

Figure 2. Location in ordination space (correspondence analysis, CA) of the first and second axis of diatom taxa. Taxa shown in the diagram were found at least in 5\% of all samples (taxa codes correspond to those in appendix A)

Figure 3. Canonical correspondence analysis (CCA) of diatom communities in streams of NW Ireland in the ordination space of first and second axis (ALK: alkalinity; ALT: altitude; COND: conductivity; TEMP: temperature; u/s AREA: upstream area); (a) ordination of diatom species, (b) ordination of sampling locations with significant and independent environmental variables (taxa and sample site codes correspond to those Appendix A and B)

Figure 4. Canonical correspondence analysis (CCA) of diatom assemblages after a major flood in the ordination space of first and second axis 


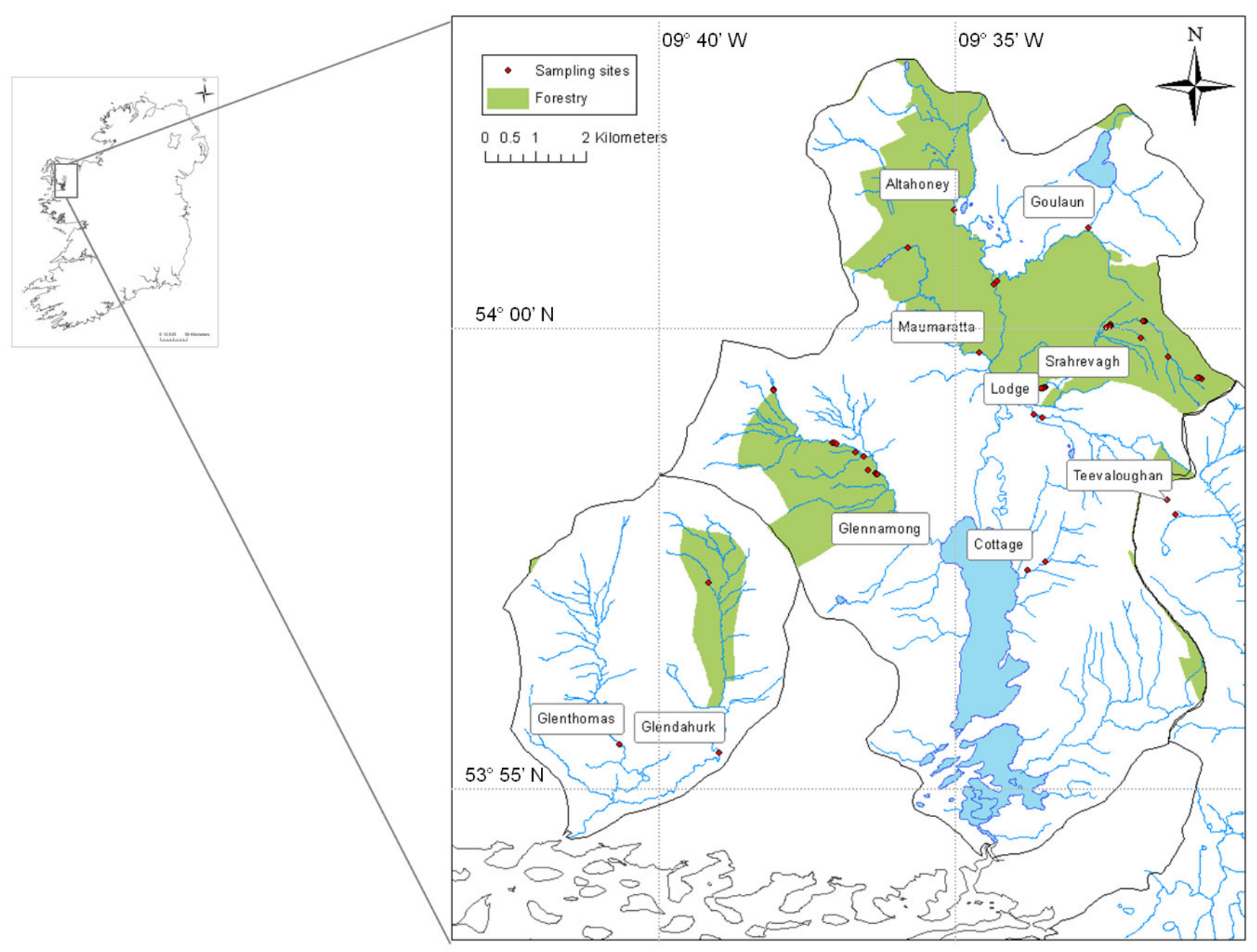

Figure 1 


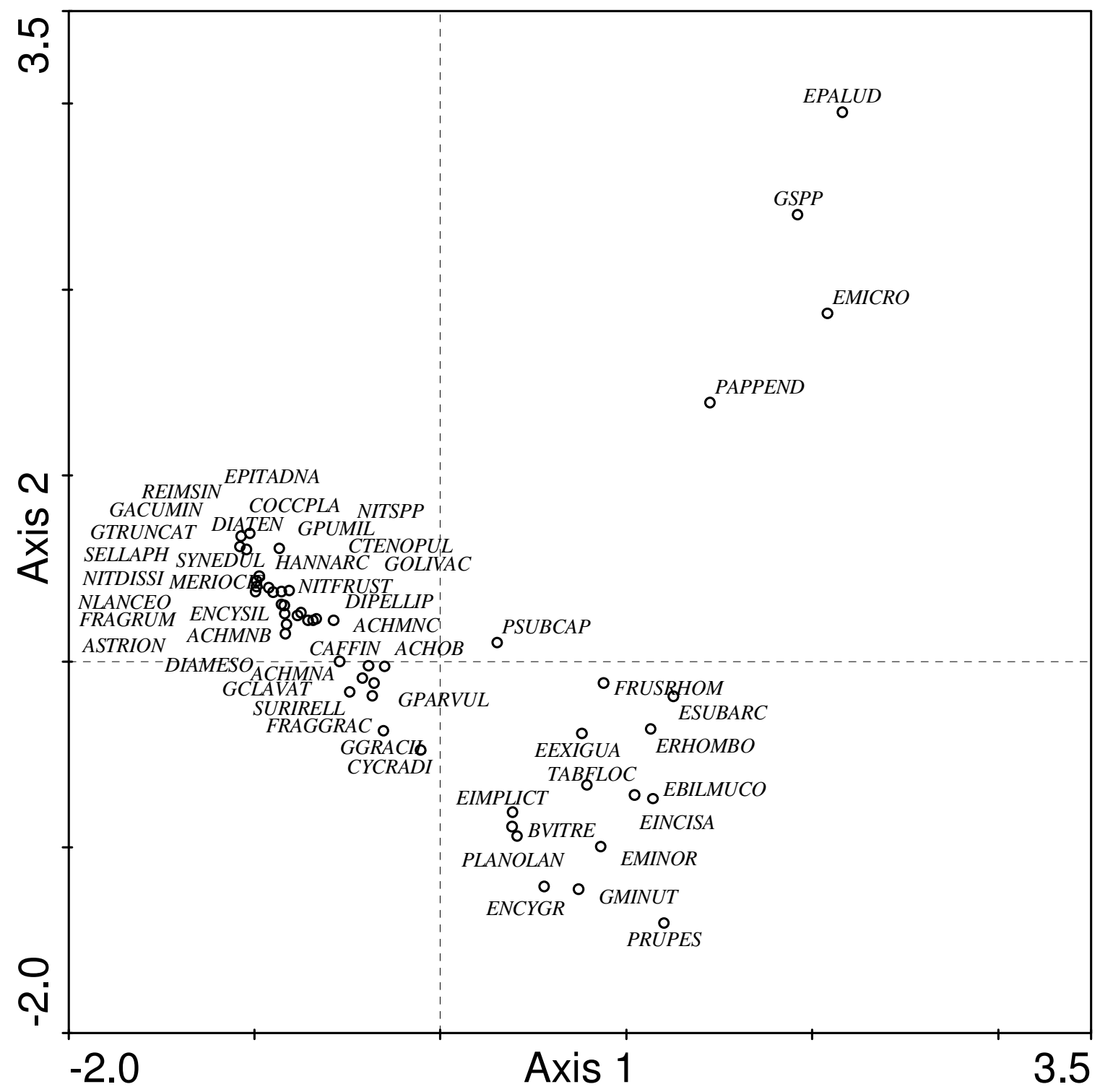

Figure 2 


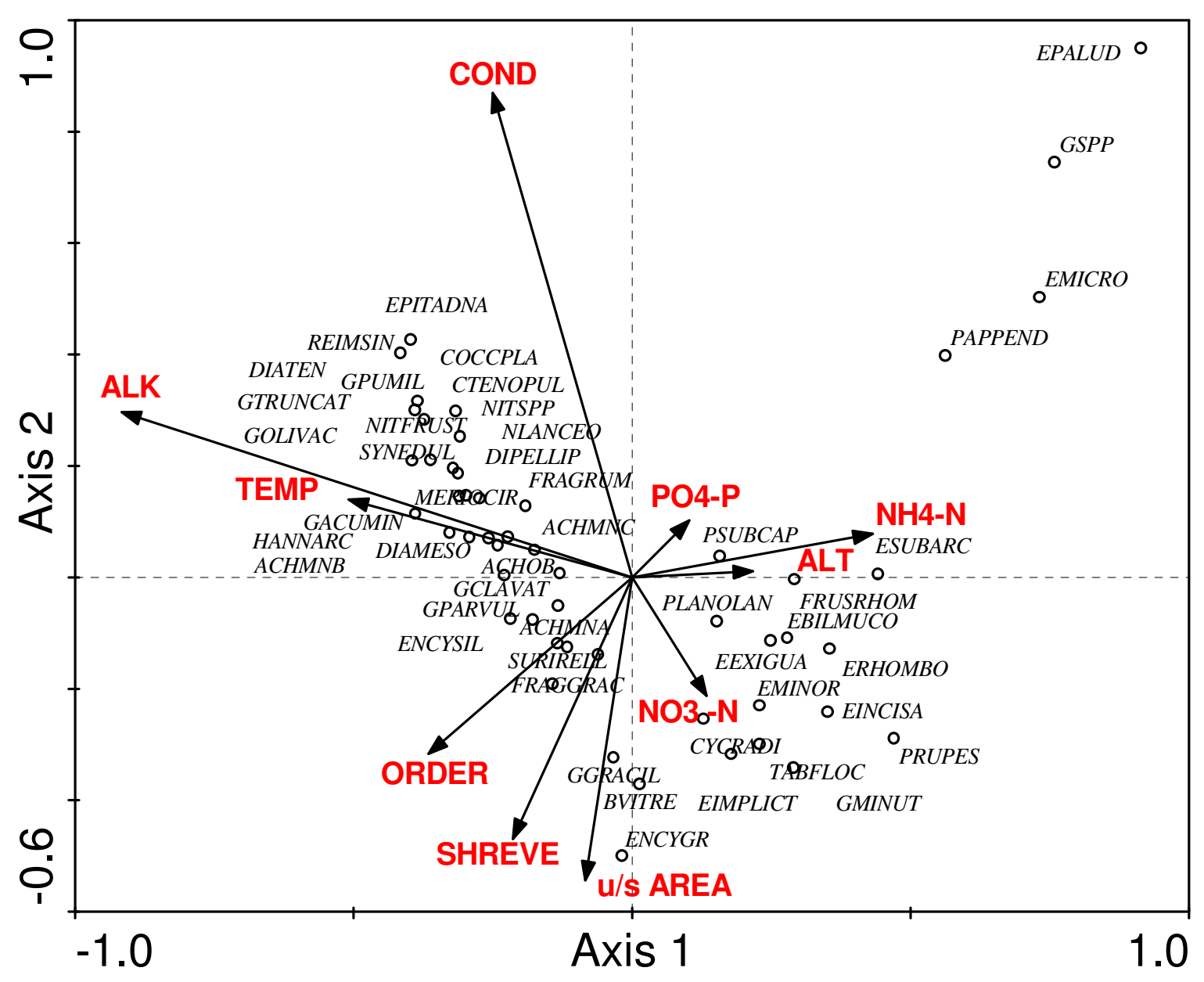

Figure $3 \mathrm{a}$ 


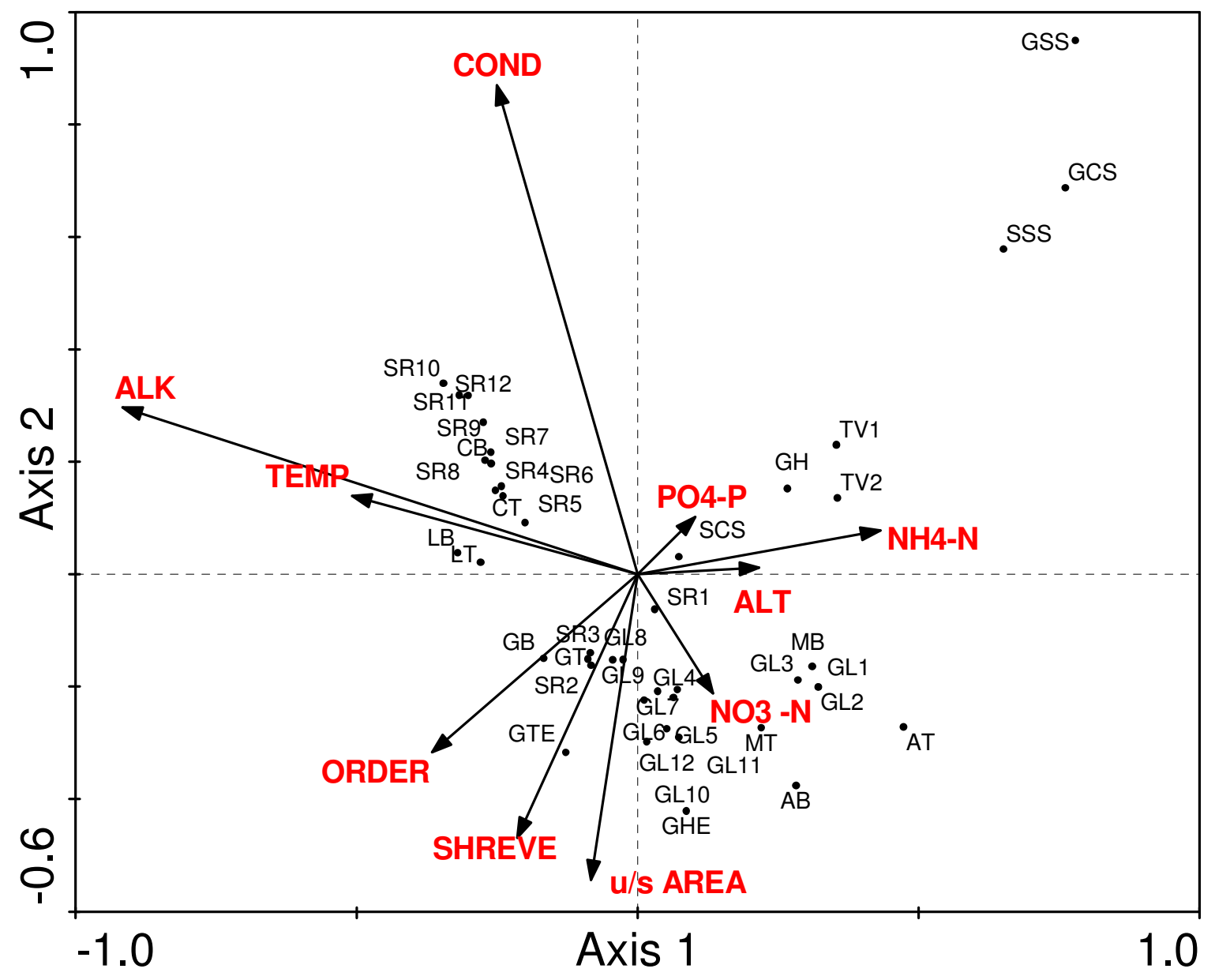

Figure $3 b$ 


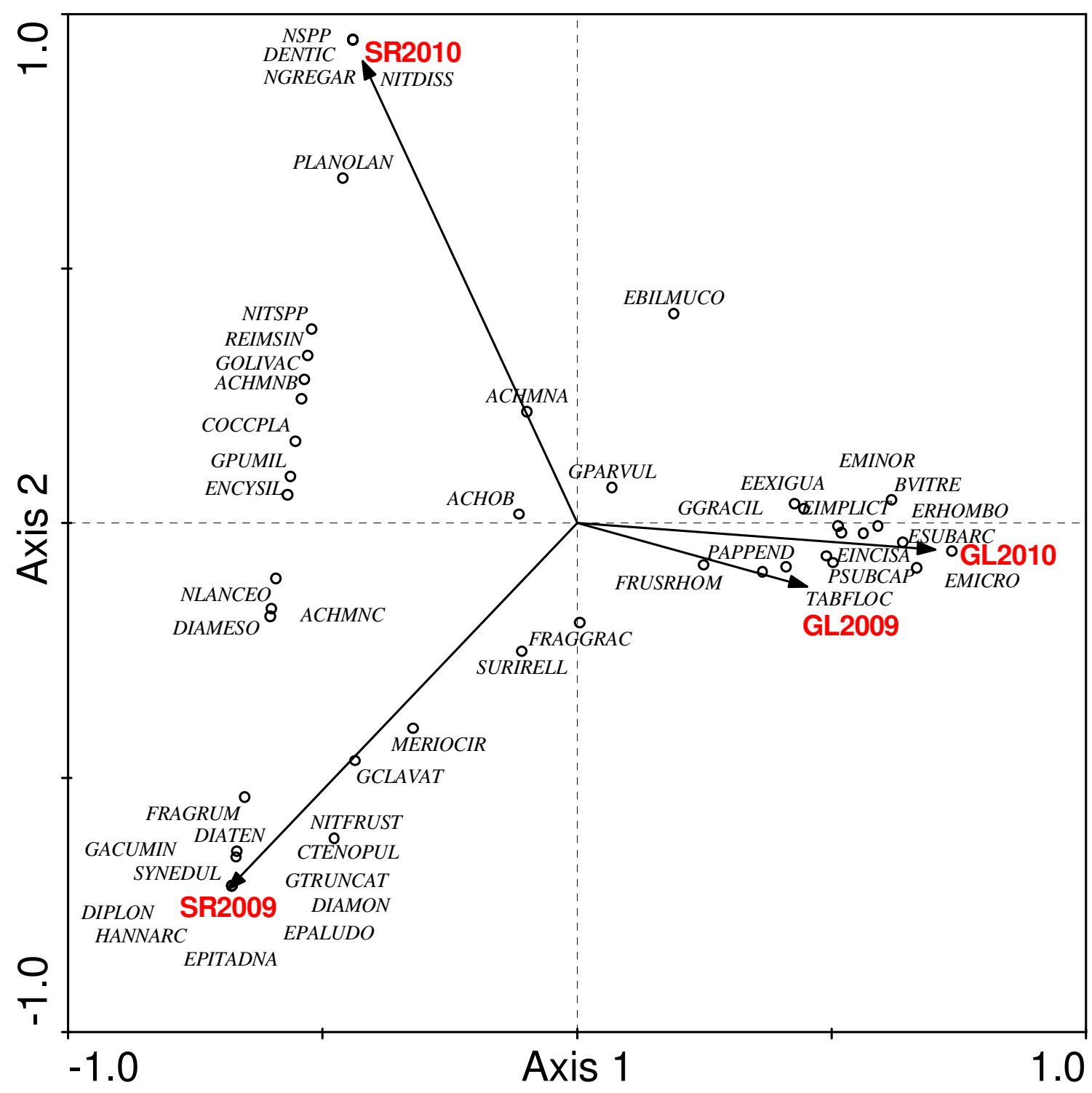

Figure 4 
